\title{
THE CHILEAN MUSEUM OF SOLIDARITY AND TRANSREGIONAL LINKS WITH ROMANIA DURING THE COLD WAR
}

\author{
Caterina PREDA, PhD \\ Department of Political Science, University of Bucharest, Romania \\ caterinapreda@gmail.com
}

\begin{abstract}
This article analyses the transregional connections established by the Chilean Museum of Solidarity with socialist countries in Eastern Europe, and in particular with Romania. The analysis employs theories of the cultural Cold War, transnational and transregional studies, and especially the transnational and cross-regional analysis of cultural relations and artistic expressions, to discuss an example of "cultural transnationalism" (Dragostinova and Fidelis) of the Socialist Second World. Through a micro-history approach of the Global Cold War regarding the relationship between Romania and the Museum of Solidarity, this study aims to enhance the understanding of relations between the East and the South as being politicized by the highly bureaucratized cultural institutions. If cultural relations were important in establishing an autonomous policy such as that of Ceausescu, the type of artistic exchanges promoted were the expression of an aesthetic paradox, supporting a traditionalist, nationalist version of art.
\end{abstract}

Keywords: Museum of Solidarity, Cold War, transregional, Chile, Romania.

\section{Introduction}

During the Cold War, cultural relations between the countries in the Soviet bloc and Eastern Europe were not exclusive to one another. This article includes evidence of the collaboration of Eastern European socialist countries with socialist countries in Latin America through the specific case of the Museo de la Solidaridad (Museum of Solidarity) created in Chile in 1971 and its relationship with Romania.

In 1971, the Chilean socialist government of Salvador Allende (1970-1973) established in Santiago a museum based on donations by artists from around the world: the Museo de la Solidaridad (the Museum of Solidarity). It was the first museum in the Americas entirely based on donations from artists intending to create a public collection for Chilean citizens. In the period between 1971-1973, the Museum received hundreds of donations from several countries and artists 
around the world. After the military coup of 11 September 1973, the Museum was transformed into the International Museum of Resistance Salvador Allende (MIRSA, 1975-1990), and went into exile to Europe, only to return to Santiago in 1990 as the Museum of Solidarity Salvador Allende (MSSA).

As this is a rather novel case study that has not been thoroughly analysed before, it is important to examine it through an interdisciplinary lens at the intersection of transregional and transnational connections, as a focus for the study of cultural relations of the "Second Socialist World" during the Cold War (Cultural Cold War studies). From a methodological point of view, an institutional archive-based study of the cultural policies of the socialist regimes during the Cold War was undertaken. Following this, a transregional examination of the role of institutions, such as the Museum of Solidarity, in line with studies that have investigated transnational relations between communist regimes was carried out. Significantly, South/East relations were examined in this study, as opposed to East-West or East-East relations exclusively.

The article will provide a detailed analysis, through a micro-history approach ${ }^{1}$ to the global Cold War, of the relations between the Museum of Solidarity and socialist Romania, situating this example of socialist cultural exchange into the broader context of the cultural relations between the two countries during the 1970s. Drawing on empirical evidence from the Romanian archives (Foreign Affairs and Diplomatic Cultural affairs) this article examines previously unseen institutional documents that offer insight into a specific type of relationship during the Cold War, through the example of the Museum of Solidarity, and "the transnational connections that this museum created across nations" (Velázquez 2018).

Although the memory of this collaboration is not a priority for either of the two countries, their connection was strong as demonstrated by the fact that Romania was one of the communist countries that received an important number of Chilean refugees after the coup of September the $11^{\text {th }}, 1973$.

So, the research method this article employs is that of the qualitative analysis of a case study (the Museum of Solidarity) of the relationship between art and politics during the Cold War

\footnotetext{
${ }^{1}$ A micro history approach allows for a small scale, individual focus instead of the large scale of historical macronarratives that use quantitative measures that can grant a different perspective on the individual case. This approach has been promoted since the 1970s by Italian historians such as Carlo Ginzburg, Giovanni Levi, Eduardo Grendi, etc. See also: : www.microhistory.org.
} 
that is examined through a transregional interdisciplinary approach that uses previously unseen archival files. The relevance of this approach is that through a detailed analysis of the transregional relationship of two socialist countries, the understanding of the role of art and culture in the context of the Cold War can further increase the broader importance of studying in more detail art's political role in non-democratic configurations.

This article's hypothesis is that a look at the cultural relations established by the Eastern European socialist regimes serves to disentangle the degree of autonomy of these regimes in relation to Moscow. For some countries, such as Romania, cultural relations were important in establishing an autonomous policy such as that of Ceausescu, but the type of artistic exchanges promoted witnessed an aesthetic paradox, supporting a traditionalist, nationalist version of art.

The article concludes by drawing some implications of this analysis for the future study of cultural relations between the socialist countries in Eastern Europe and Latin America during the Cold War.

\section{A trans-regional study of cultural exchanges between socialist regimes in Latin} America and Eastern Europe during the Cold War

This article proposes to use a unique case study of transnational and transregional links, the Museum of Solidarity so as to understand one more layer of cultural relations as they were established during the Cold War between socialist countries in the South and the East.

If transregional studies have studied connections between regions, taking their inspiration from the spatial turn in the humanities and social sciences, they have not been used extensively to study the connections established during the Cold War. (Middell, 2019, 10). Conversely, transnational studies have recently included a look at communist regimes, but emphasis has been laid on the relations of Eastern European countries with each other and with the Western countries, and not extensively with the socialist countries of the South (Apor Iordachi, 2013). Using a transnational approach to study communist regimes encompasses a look at different scales of understanding, entanglements and circulations, as does the study of the Global South from a perspective of cultural history (Iacob, 2013, 114). The role of individuals and of personal ties has been considered essential by transnational analyses and is a very important aspect to the understanding of the Museum of Solidarity' establishment and functioning both during its Chilean 
phase and through its exile stage, but as I shall show, not for the Romanian case and its donations to the Museum (Wenderski, 2015, 2; Iacob, 2013, 123).

In line with the transnational history of art as proposed by Jerôme Bazin, Pascal Dubourg and Piotr Piotrowski (Bazin, Dubourg, Piotrowski, 2016, 1), this article looks at the role played by the Museum of Solidarity as a transnational institution in establishing a new geography of art exchanges between the South and the East. The Museum of Solidarity is perhaps one of the best examples of transnational and even transregional networks of collaboration, including artists, curators, and art critics from the Americas and Europe. While there are other examples that highlight the collaboration of artists, such as the Museum of Nicaragua or the Museum of Lodz, Poland, none of them goes as far as the Museum of Solidarity in terms of transnational links. The connections with the West included "a complex circulation of objects, persons and ideas, as well as transactions between East and West [were seen] through the Iron Curtain." (Bazin, Dubourg, Piotrowski, 2016, 1-2). I propose to investigate this kind of relations also with the South.

Piotrowski's study of art in Eastern Europe in a global perspective in accordance with what the Polish art historian called the "horizontal art history" can be a starting point of this kind of analysis. In Globalising the Art of East-Central Europe Piotrowski proposes a project of comparative studies of "geohistorical margins and marginalized cultures of the East and Global South, the Far North, and every other part of the globe located outside the centre-based understanding of culture" (Piotrowski 2018). Piotrowski's project of 'globalizing Eastern Europe' aimed to combine his approach of "horizontal art history" with the practice of "provincializing the centres" and aimed to show how Western models supposedly followed in the peripheries had to be understood in their contexts as well (Hock, 2018, 3).

While scientific literature has shown limited interest in these transregional links, several contemporary artists have investigated transregional solidarity of left-wing movements of the 1960s and 1970s, particularly as part of the Non-Aligned Movement (NAM), through their work. For example, the exhibition "Past Disquiet. Narratives and Ghosts from the International Art Exhibition for Palestine, 1978" (20 February - 1 June 2015, Museum of Contemporary Art in Barcelona) curated by Rasha Salti and Kristine Khouri recuperated the stories of several solidarityrelated museum initiatives of the 1970s: The International Resistance Museum Salvador Allende, the Artists of the World against Apartheid, Art for the People of Nicaragua, the Salon de Jeune Peinture, the International Brigades of Anti-Fascist Painters, the Japan Afro-Asian Latin American 
Artists Association and the 1974 and 1976 Arab Biennials (Exhibition Past Disquiet). Documenting the influence of the Chilean example on projects in other regions, the exhibition subsequently travelled to the Museum of Solidarity Salvador Allende in Santiago, Chile under the title "Pasado Inquieto" (7 April - 12 August 2018). As the two curators remarked, their forensic investigation of the Palestinian exhibition of 1978 led them to discover a "wider, transnational meshwork, composed of artists committed to political struggles, and of militants who could not imagine conducting their struggles without them" (Khouri, Salit, 2019).

Furthermore, the focus on cultural practices during the Cold War, or "the battle for the hearts and minds" (Stonor Saunders, 1999) is a recent focus, which has only limitedly involved other regions besides the United States and the Soviet Union, and if studies have been done on other places they were conceptualized from the perspective of their relationship with the two powers (Stonor Saunders, 1999; Leffler and Westad, 2012; Gould-Davies, 2003).

In what concerns the two regions under analysis here, Eastern Europe and Latin America, they have been studied separately, with very few studies examining the cultural connections between the two during the Cold War. Gould-Davies has underlined how a new cultural approach could be fruitfully mixed with Cold War history using new Eastern European sources (GouldDavies, 2003, 193). And with respect to Latin America, recently, "a new history of the Latin American Cold War - rather than just a history of the Cold War in Latin America" has emerged (Joseph, 2019, 9). This new focus is part of the "rise of ambitious transnational and transregional analysis, steeped in multi-sited, multi-archival (and often oral history) research strategies" (Joseph, 2019, 10). In this sense, many of the studies on the cultural Cold War in the region have looked at the intellectuals and artists that were important in the conflict, and only recently a new trend has seen a focus on experts' roles highlighting as well "transnational contact zones" which have favored new forms of power, including that of networks of artists and intellectuals, such as those involved in the establishment and organization of the MS and MIRSA (Joseph, 2019, 20-22). This type of study can be part of the examination of "cultural relations with the Socialist Second World" (Joseph, 2019).

Moreover, the contacts between the East and the South have been studied for example from the perspective of the cultural policies of Eastern European socialist countries in Latin America (Zourek 2016, Dragostinova 2018). At the same time, these studies have focused on official 
exchanges and networks (Rupprecht 2015, Braghoorn, 1976; Pedemonte 2010), and less on "the role of different layers of people in transnational networks" (Mikkonen and Koivunen, 2015, 3).

In a recent article, Dragostinova and Fidelis argue for analysis of the role of East European socialist regimes from the perspective of the "Second World" (socialist countries) that highlight their autonomy in relation to the Soviet Union (Mikkonen and Koivunen, 2015, 14; Dragostinova and Fidelis, 2018, 582, 587). The two authors support the use of transnational methodologies that blend a cultural history approach with transnational history under the term of "cultural transnationalism." This approach is similar to what Simo Mikkonen and Pia Koivunen call "cultural internationalism that consisted in the cross-national communication, understanding and cooperation" (Dragostinova and Fidelis, 2018, 585; Mikkonen and Koivunen, 2015, 10). This perspective allows for a more in-depth study of East-South relations and of the different "crossings" between the Iron Curtain and into the Global South (Dragostinova and Fidelis, 2018, 587).

Thus, this article proposes an analysis as part of the focus on "cultural transnationalism" or "cultural internationalism" between the South and the East, or of the "Socialist Second World". It also takes into account Piotrowski's concept of horizontal art history and his call to see the union between the marginalized East and the Global South, as well as the discussion put forward by the artistic projects which engaged with the transregional solidarity of artists during the later stages of the Cold War. This analysis examines the constellations of transregional relationships as mediated through institutional collaboration practices of the Cold War period through the case of the Museum of Solidarity. At the same time, the case study chosen, that of the relation with Romania, shows the limit of this model that emphasizes personal ties and not institutional contacts.

This article makes three claims. First of all, it provides further empirical information to support Dragostinova's find that, in order to better understand the dynamics of the Cold War, it is important to study "the Second Socialist World". I argue here, in the line of Dragostinova, that in order to understand how the autonomy of Eastern European countries from the Soviet Union functioned and how they used their cultural action as a strategy to establish their global presence, it is interesting to study cultural relations between the countries of the Second Socialist World (Dragostinova and Fidelis, 2018, 582, 587).

The second claim this article makes is that relations between the socialist countries in the East and South are not uniform, but are examples that show how multi-layered practices interacted. 
In fact, the Romanian example is different then the other socialist countries. As this article will show, even if Ceausescu was considered as "an independent leader" inside the bloc of Eastern European countries, at a closer look, it can be seen how the choices made in relation to the Museum of Solidarity elucidate his true stance on art.

Thirdly, contrary to the relationship organized between Western artists and the Museum, the relation with socialist countries such as Romania was based on institutional exchanges that were highly bureaucratized. This article demonstrates that, if the relation between Chile and Romania is a good example of transnational links in which individuals, rather than states interact to create cultural institutions of exchange, in what concerns the case of the Museum of Solidarity and its transregional links, it is rather an example of it being taken over by the institutionalized framework of the Union of artists, and not of the personal choice of the artists.

So, this study brings a new focus which employs the perspective of "horizontal art history" through the lens of the connections established by the Museum of Solidarity between the East and the South. At the same time, it discusses the aesthetic paradox of Romanian cultural policies. Even if Ceausescu acting as an autonomous leader used cultural means to strengthen this image, the art promoted was traditionalist, nationalist and not liberating.

\section{Cultural transnationalism: the Museum of Solidarity (1971-1973) \& the International Museum of Resistance Salvador Allende (MIRSA) (1975-1990)}

The regime of Salvador Allende (1970-1973) inaugurated "the Chilean way to socialism" that produced a series of important changes in Chile in just 1000 days of government that ended abruptly with the military coup d'état of September the $11^{\text {th }}, 1973$. Supported by the broad coalition of Popular Unity (UP) Salvador Allende enacted a comprehensive agrarian reform, nationalized the exploitation of copper, as well as of other industries, and helped strengthen a new model for the administration and production of Chilean culture. He consolidated Chile's foreign relations with Cuba and the Soviet Union, but the USSR's economic help did not meet Allende's expectations. Increasingly, the political decisions of Allende, as well as the resistance of rightwing segments supported by the US government, even before the confirmation of Allende as president, provoked an intensely polarized situation, which led to the golpe.

The cultural policy of the Allende regime looked to strengthen the state's role in cultural affairs. The Chilean cultural institutional model was based on the action of three actors: the state, 
which dealt with the safeguard of the patrimony (DIBAM), the universities that created cultural institutions, and the municipalities, which dealt with the distribution of culture. The increased role of the state in cultural affairs included the nationalization of the Zig-Zag publishing house and its transformation in 1971 in the Editorial Nacional Quimantú, which published cheap books on literature, social and economical issues. Film through the 1970 Manifesto of the Filmmakers of the UP and the nationalization of Chile Films, theatre with the amateur groups that performed in factories, the visual arts with the muralist brigades such as the Ramona Parra Brigade, music with the New Song movement all participated to this period of cultural effervescence promoted by the Allende regime. Important institutions created by the Allende regime include the Institute of Latin American Art (1970) - that depended of the Faculty of Fine Arts of the University of Chile - and which organized meetings such as the Encuentros de artistas plásticos del Cono Sur (Chile, 1972) that reunited artists from the Southern Cone in Santiago and collaborated with the House of the Americas in Havana.

Another important institution founded by Allende was the Museum of Solidarity with a call to "artists of the world" to donate artworks for a museum of modern art for the people of Chile. This era is also known as the period of Solidarity (1971-1973) (Rojas Mix, 2016, 18). Since 1975, and until 1990, in exile, it became the International Museum of Resistance Salvador Allende (MIRSA), and this period is known as that of Resistance (1975-1990); thereafter the Museum of Solidarity Salvador Allende (MSSA) reopened in Santiago de Chile in 1991 and is still active today.

The Museum remains to this date one of the most interesting examples of committed artists who collaborate to create a space for the popular classes to enjoy contemporary art. It was created as "a museum against museums, an antimuseum" that "questioned their geopolitical monopoly by calling out the absolute incompatibility of their social function and the principles of the artworks (and artists) in their care" (Berríos, 2017, 140). The Museum is a unique case study that can help us better understand the role played by the networks of intellectuals and artists in the movements of international solidarity (Lebeau, 2018 a, 9).

The Institute of Latin American Art, which coordinated the Museum of Contemporary Art (MAC), assisted the Museum of Solidarity in its endeavours. Another source of assistance was the International Committee of Artistic Solidarity with Chile (CISAC, 1971), which was presided by Mario Pedrosa, who was the director of the Sao Paulo Biennial, and formed by curators, and 
directors of international museums. The first exhibition of the museum was planned to coincide with the inauguration of the United Nations Conference on Trade and Development, UNCTAD III (April-May 1972), Santiago (Zaldivar, 2013,39). The Solidarity collection included "artworks that supported the "Chilean way to Socialism"' with vanguard artworks in opposition to the Latin American socialist realism and its Mexican revolution and Cuban Revolution references (Miranda, 2013, 109).

After the military intervention of September 1973, the Museum was reorganized in exile in 1975, but continued to collect artworks from artists and museums. Elodie Lebeau called this stage "the museum in exile" while Carla Machiavello labeled it "the museums of resistance", stressing the diversity of the collections in the different countries. The International Museum of Resistance Salvador Allende was “eminently transnational” (Lebeau, 2019, 338) and represents a unique case in the manifestations of transnational solidarity with Chile. It was connected to the institutional sphere and to the political party apparatus of the countries where it implanted itself (Lebeau 2018 a, 9). This transnational institution was structured by national committees that were created in Cuba, Spain, France and Mexico, which had a task to reunite artwork donated by artists who were in solidarity with the Chilean cause (Lebeau 2018 a, 6). For Lebeau the committees were inter-related, and not independent, and their capacity to gather artworks depended on the countries in which it took place ((Lebeau 2018 a, 8; Lebeau, 2019, 334). These artworks were exhibited in different venues during the military regime, "from festivals to international solidarity events" with a clear message against the dictatorship; often, murals were produced by the anti-fascist brigades formed by Chilean and Latin American artists with their European collaborators (Berríos, 2017, $142,143)$.

The MIRSA was founded in Paris in 1975, as a reaction to the establishment of the dictatorship in Chile, and under the direction of those that created it in 1971 who were forced into exile (Zaldivar, 2016, 9). The role of the new museum was to denounce the military dictatorship in Chile and to create new forms of solidarity. A new decentralized network of support was created and artists were invited to donate their work with an explicit political objective - that of supporting the "resistance" of Chileans (Zaldivar, 2016, 9). Thus, more than 1,000 -1,100 artworks were donated between 1976 and 1990 (Zaldivar, 2016, 10; Machiavello, 2016, 90). Since 1976, MIRSA collections were created in Cuba, Panama, Colombia, France, Mexico, Spain, Sweden, Poland, Finland and Algeria (Yasky, 2016, 85). 
In exile, several artists supported the museum. In Paris there was a Secretariat formed by Mário Pedrosa, José Balmes, Pedro Miras, Miria Contreras (in Cuba) and Miguel Rojas Mix (Rojas Mix, 2016, 20). A very interesting example of support by artists is that of the Venice Biennial of 1974, which was cancelled by its director, Carlo Ripa di Meana, who instead organized an event entitled "Freedom for Chile". This event focused on the International Brigade of Antifascist Painters (created in 1975) in which took part Balmes and Guillermo Núñez (Machiavello, 2016, $58,60)$. Following the model, which developed during the Allende regime, other brigades were established in European countries such as Sweden.

A similar project to that of the Museum of Solidarity was the Museum of Solidarity with Nicaragua/Art for the people of Nicaragua ${ }^{2}$ (1982) supported by Carmen Waugh. After helping the museum in Nicaragua, Waugh returned to Chile in 1984 and assisted with the arrival of artworks for the Museum of Solidarity Salvador Allende (MSSA), of which she became the director after 1991. Since 1991 the Museum was reorganized in Chile and was directed with Waugh (until 2005) by José Balmes (2005-2010), Ernesto Ottone (2010-2011) and by Claudia Zaldívar since 2011.

\section{Transregional donations from the Socialist Second World (1970-1990)}

In what regards relations with Eastern European countries, diplomatic relations with Chile were established during the Eduardo Frei presidency (1964-1970) (Yordanov, 2019, 61). During the Allende regime, despite an effort to receive more economic support from the Eastern bloc countries and the USSR, there was certain scepticism among these governments in relation to the "Chilean experiment" (Yordanov, 2019, 68; Zourek, 2014, 214). Then, following the military coup, the Soviet Union suspended diplomatic relations with Chile on 21 September 1973 and the other countries, with the exception of Romania, did the same (Zourek, 2014, 215).

In relation to the Museum of Solidarity, under the coordination of the Ministry of Foreign Affairs of Chile, donations were received until the coup d'état of September 11, 1973. The shipments from artists were organized through the Institute of Latin American Art and the Chilean embassies abroad. There was also an international convocation assembled by ambassadors and

\footnotetext{
${ }^{2}$ The Museum of Solidarity with Nicaragua was afterwards called Museum of Contemporary Latin American Art/Museum of Art of the Americas/Museum Julio Cortázar.
} 
cultural attaches that allowed for direct donations to the embassies. This demonstrates the Solidarity Collection was eclectic in terms of the quality and importance of the artworks; moreover, there were more engravings and fewer sculptures because they were being transported with the diplomatic suitcase (Miranda, 110). Thus, in the initial period, the museum was able to collect over 700 artworks through donations (Berrios, 2017, 133).

Interestingly, from the statistical list of the Museum of Solidarity, we find that the socialist countries were not the main collaborators of the Museum. From a total of 823 artists whose artworks are part of the collection, most socialist artists were from Poland (36), Bulgaria (21), USSR (16), Cuba (12), Mongolia (8), Hungary (2), Romania (2) and Czechoslovakia (1) (Museo, $2016,124)$. With respect to the artwork, from a total of 1,161, 74 were originally from Cuba (74 or $6.37 \%$ ), Poland (46 or 3.96\%), Bulgaria (32 or 2.76\%), USSR (23 or 1.98\%), Yugoslavia (9 or 0.78\%), Romania (3 or 0.26\%), Hungary (2 or 0.17\%) and Czechoslovakia (1 or 0.09\%) (Museo, $2016,124)$. From the 1,161 works by 823 artists of 48 different nationalities, a majority came from Western Europe (51\% of artworks), and Latin America (34 \%), while those from Eastern Europe (11\%) were fewer (Lebeau, 2018 b, 2). Another interesting detail is that the Cuban collection of MIRSA includes both Latin American artists and artists from Socialist European countries (the Soviet Union, Mongolia and Bulgaria) and Asian countries (Machiavello, 2016, 89).

The artworks donated to the museum were diverse, including paintings, sculptures, graphic art and photography, authored by both professional artists and amateur artists. The topics of their work are similar and include: "the war in Vietnam, the Cold War, the interventionism of the USA in Latin America and other regions, scenes of repression and violation of human rights, homage to Salvador Allende and the Chilean people, rejection of Pinochet and the members of the military junta in Chile, and the call to the liberation of figures such as Angela Davis" (Machiavello, 2016, 89). Lebeau observed that the artwork donated to the MIRSA had a "transnational imaginary along with a transhistorical imaginary of the fight against fascism" (Lebeau, 2018 b, 7). On the contrary, solidarity manifested differently in Eastern Europe, as "in the so-called real socialist countries in Eastern Europe, solidarity largely met the need to revitalize the revolutionary and internationalist ethos of regimes that were going into decline" (Lebeau, 2019, 337). The Polish sent abstract artworks for the International Exhibition UNCTAD III organized in Santiago by the National Museum of Fine Art (MNBA), which were donated thereafter to the Museum of Solidarity, including works by: Stefan Gieroswski, Warszawa (1968), Dominik Tadeusz, Kamienie (1969), 
Jan Tarasin, Koleckja (1971) (Miranda, 131).

Out of the Eastern European countries, Poland was the most active. From Poland the most important actors were the Polish Committee of Solidarity with the people of Chile, led by Edmund Jan Osmanczyk, the director of the Museum of Art in Lodz, Ryszard Stanislawski, the director of the Museum of Art in Lodz, and the Ministry of Culture and Art of the Popular Republic of Poland. Poland was one of the first countries to establish a Solidarity Committee with Chile, and Ryszard Stanislawski was in charge of the selection of the donations (Museo, 2016, 394). Ryszard underlined the common origin of the two institutions, as their collections were based on the solidarity of international artists (Museo, 2016, 394). Between June 4 and July 23, 1978 artists from Poland donated to the MIRSA and were exhibited in the Art Museum in Lodz. Poland donated 44 artworks (a total of 1,161 artworks) to the museum and organized an exhibition in June 1978 in Lodz, which subsequently travelled to Havana, Cuba. ${ }^{3}$ According to Maria José Delpiano, who curated an exhibition on the connection between the Museum in Lodz and the Museum in Santiago, 50 artworks were donated to the MIRSA (Exhibition "Museo de arte de Lodz"). In December 1978 there was a Polish exhibition of their donations to the MIRSA in the Galería Centro de Arte Internacional, in Havana, Cuba, and in January 1980 there was an exhibition of Chilean arpilleras and molas from Panama in the Gallery TPSP from Warsaw (Museo, 2016, 105, 106). Thus, the collaboration with socialist countries was rather institutional, and in the instances collaboration developed outside of the official framework, it was because of personal ties, as the Polish example shows.

Chilean-Romanian cultural relations and the Romanian missing donation to the Museum of Solidarity

The regime of Nicolae Ceausescu (1965-1989) wanted to present itself as autonomous in relation to Moscow and it did not end relations with the Pinochet regime after the military intervention of 1973 arguing Romania had relations with countries, not with governments. Ceausescu even stressed his independence in taking the decision of condemning the coup by saying

\footnotetext{
3 The exhibition of Polish artworks donated to the MIRSA was organized by the Ministry of culture and the arts of Poland, the Polish Committee of Solidarity with Chile, and the Art Museum of Lodz. Museo Internacional de la Resistencia Salvador Allende 1975-1990, Catalogue raisonné.
} 
"we were the first to protest and we did not wait for someone to tell us to protest or not", ${ }^{4}$ but then decided to maintain relations with the Pinochet regime.

Ceausescu diversified Romania's foreign policy trying to establish connections with countries in Latin America and Africa and used cultural relations to strengthen this autonomous policy in relation to countries in the Third World. Following the coup of September 1973, Chilean refugees were received by the Romanian communist regime with the direct intervention of Nicolae Ceaușescu. The Romanian communist leader was supposed to visit Chile in August 1973 and several events had been prepared for his official visit, but this plan was not accomplished. According to archival Romanian official documents, until October 1974 Romanian authorities had accepted 1.600 Chilean refugees (members of the Communist Party, of the Socialist Party, of MAPU, the Radical Party and sympathizers of the UP), of which 1.300 were in Romania in December 1974 and were given by Romanian authorities, shelter, a job or a scholarship. ${ }^{5}$

The cultural policy of the Ceauşescu regime combined a nationalist perspective, clearly expressed after 1971, with a socialist imperative. Art had to mirror the social reality and help build the new "multilaterally developed society", while respecting the party line as expressed by the Romanian leader himself. So, artists had to serve the fatherland and find inspiration in the previous accomplishments of Romanian cultural figures. In the visual arts this lead to the imposition of the so-called "humanist realism" after Socialist Realism was abandoned. This meant that the cult of Ceaușescu became increasingly present in the arts, but also that a nationalist art was promoted. Artists tended to adapt to this new logic, in order to be able to continue to create their own art and to have certain advantages.

Cultural exchanges between Romania and Chile were intermediated by the Cultural relations section of the Ministry of Foreign Affairs, the Romanian Institute for Cultural Relations Abroad (IRRCS), the Ministry of Culture (called the State Committee for Culture and the Arts (CSCA), and then since 1971 the Council for Culture and Socialist Education (CCES)), and by creative unions such as the Union of Artists (UAP).

The Romanian Institute for Cultural Relations Abroad (IRRCS, 1948) was established by the Romanian communist regime (1948-1989) to handle cultural relations with foreign countries.

\footnotetext{
${ }^{4}$ File 297/1974, Fund 3285 (The Central Committee of the Romanian Communist Party, Foreign Relations Section), Romanian Central National Historical Archives (ANIC), 4. ${ }^{5}$ Ibid., 8.
} 
This institution was similar to the Soviet Union model, the "All Union Society for Cultural Ties" (VOKS, 1925), and its subsequent transformations in the "Union of Soviet Societies of Friendship and Cultural Relations with Foreign Countries" (SSOD, 1957), as well as the State Committee for Cultural Ties (GKKS, 1957). The archives of the IRRCS safeguard details concerning the friendship associations with countries in Latin America including Chile. Furthermore, the archives of the Ministry of Foreign Affairs document the cultural relations Romania had with Chile during the Allende regime (1970-1973), but also prior to 1970 and after 1973. In fact, the IRRCS witnessed the change of foreign policy the Ceausescu regime enforced after 1968 and observed thus a transcontinental turning point for cultural relations, which were strengthened with Africa and Asia, as well as with Latin American countries.

Moreover, the first important actor of cultural relations between Romania and Chile was the Chilean-Romanian Institute of Culture (ICCR) established in Santiago de Chile in $1952 .{ }^{6}$ In this case, cultural relations preceded the establishment of reciprocal embassies in the two countries; the Romanian embassy opened in Santiago in 1965 and the Chilean embassy opened in Bucharest in $1966 .{ }^{7}$ Humberto Mewes presided over the Institute in Santiago in the 1950s and 1960s with the poet Nicanor Parra as vice-president in 1960. In 1973 it was presided over by one of the most important Chilean painters, Nemesio Antúnez, who also visited Romania in the same year. According to a document of the IRRCS of 1970, the Institute of Santiago was under the patronage of the University of Chile. In 1971 the Commission of intellectual cooperation of the University (which coordinated the bi-national institutes) appointed as its president, Nemesio Antúnez. $^{8}$

The Institute organized events for the Romanian national day of August 23, including exhibitions of photography and popular art (handicraft), theater plays, etc. The Institute asked the IRRCS to send cultural materials such as books, discs, radio shows, popular art, commercial and cultural films, etc. It also requested Romanian authorities to assist in paying the rent, arguing all

\footnotetext{
${ }^{6}$ At the time known as the Chilean-Romanian Center of Culture.

${ }^{7}$ As Radoslav Yordanov shows in a recent article, this was part of a broader decision of Eduardo Frei (1964-1970) to establish relations with the communist regimes in Eastern Europe. Radoslav A. Yordanov, "Warsaw Pact Countries' Involvement in Chile from Frei to Pinochet, 1964-1973", Journal of Cold War Studies, Vol. 21, No. 3 (2019): 56-87, doi:10.1162/jcws_a_00893, 61.

${ }^{8}$ File IIB/1972, IRRCS Fund, Romanian Central National Historical Archives (ANIC).
} 
other bi-national institutes functioned with the help of the partner state. ${ }^{9}$ The Romanians sent art albums of some of the best-known Romanian artists: Ion Țuculescu, Nicolae Tonitza, Corneliu Baba, or albums of Romanian architecture and contemporary Romanian painting. They also sent Nicolae Ceaușescu's speeches to the Party congresses, in addition to Romanian literature.

In 1972 in Romania was organized an exhibition of Chilean militant graphic art; 21 engravings were exhibited and then donated by the Chilean artists to Romanian art institutions. At least from the titles of the 21 works sent by Chileans, Luis Libiot, The cat, Medardo Espinosa, Family, or Carlos Hermosilla, Old peasant they don't seem to be ideological works, but rather neutral artworks. ${ }^{10}$

In response, in June 1973, Romania sent a retrospective exhibition of "Romanian militant graphic works" to celebrate the day of August $23^{\text {rd }}$. The works sent were lost during the events that followed the military coup of September 11 1973, and were retrieved only in February 1974 when they were in the Romanian embassy in Santiago. The Romanian authorities wanted to present a selection of the works but were unsure if this type of graphic work could be presented. ${ }^{11}$ After the military intervention, the institute was searched, certain goods disappeared, and the institute was subsequently closed. ${ }^{12}$

Of note is that the Romanian authorities privileged popular, traditional artistic expressions as cultural ambassadors, and not socialist or globalist inspired artworks and cultural productions. This was also true of their relations with aspiring socialist regimes such as the Chilean one.

The second actor of this transregional cultural relationship was the Romania - Chile Friendship Association, created in May 1973 in Bucharest. Structurally, this Association had 4 acting vice presidents which included; Mihai Florescu, the Minister of Industry, with Gheorghe Achiței, Rector of the Nicolae Grigorescu Institute of Visual Arts in Bucharest, and Marcel Chirnoagă, Vice-President of the UAP.

The two institutions, in Santiago and Bucharest, seem to be the result of the actions of individuals in the two countries that acted transregionally for the establishment of cultural relations between the two countries.

\footnotetext{
${ }^{9}$ File 37/1970, IRRCS Fund, Romanian Central National Historical Archives (ANIC).

${ }^{10}$ File IIB/1972, IRRCS Fund, Romanian Central National Historical Archives (ANIC).

${ }^{11}$ File 220/1966, Chilean Fund, The Archive of the Romanian Ministry of Foreign Affairs.

${ }^{12}$ File 1540, 217/1974, Chilean Fund, The Archive of the Romanian Ministry of Foreign Affairs.
} 
The MSSA retrospective album registers, under the title "The lamentable loss of the Romanian shipment", that according to documents from the Chilean embassy in Bucharest, ${ }^{13}$ there was a Romanian shipment which included paintings and sculptures donated by the Romanian government and artists. On the Chilean side, there is no information concerning the arrival of the artwork, except for a receipt of transport from September 25, 1973 when the Museum had been closed by the military. The Romanian artists who donated were part of the Union of Artists of Romania and included some well-known artists, such as, Corneliu Baba, Alexandru Ciucurencu, Geza Vida, Ovidiu Maitec, and George Apostu. ${ }^{14}$

The Romanian National Archives have preserved a file in the Union of Artists' fund entitled "Donation to the Solidarity Museum of Chile" (September 25, 1972), which includes the list of the six artworks that were sent with short bios of the artists. ${ }^{15}$ From the titles of the artworks, these were not openly propaganda art or politicized art, but seem to be neutral artworks. The list includes some of the best-known artists: Corneliu Baba, Portrait (1972), Alexandru Ciucurencu, Landscape, Constantin Piliuță, Woman Singer, George Apostu, Father with sons, Ovidiu Maitec, Baroque gate, and Vida Geza, Character from the Maramureș fairytales. We may therefore surmise that Romania sent three paintings and three sculptures with neutral themes. The accompanying letter, addressed to the Chilean ambassador in Bucharest, states that the Romanian artists, members of the Union of Artists, having learned about the call of the "International Committee of Artistic Solidarity with Chile" for the creation, on a donations basis, of an art museum of modern and experimental art, decided to donate their artwork to this institution that would foster relations between the Romanian Socialist Republic (RSR) and Chile. ${ }^{16}$

\footnotetext{
${ }^{13}$ Official document 148/59, 23 October 1972, by the ambassador Julio Hornero and official document 130/38 of 10 July 1972, Archive MSSA in Miranda $(2013,130)$.

${ }^{14}$ Embassy of Chile in Bucharest, oficio 175/55, 9 October 1972, Archive MSSA, in Miranda (2013, 130).

${ }^{15}$ File 48/1972, UAP Fund, ANIC.

${ }^{16}$ Ibidem.
} 
Figure 1: the Romanian donation to the Museum of Solidarity ${ }^{17}$

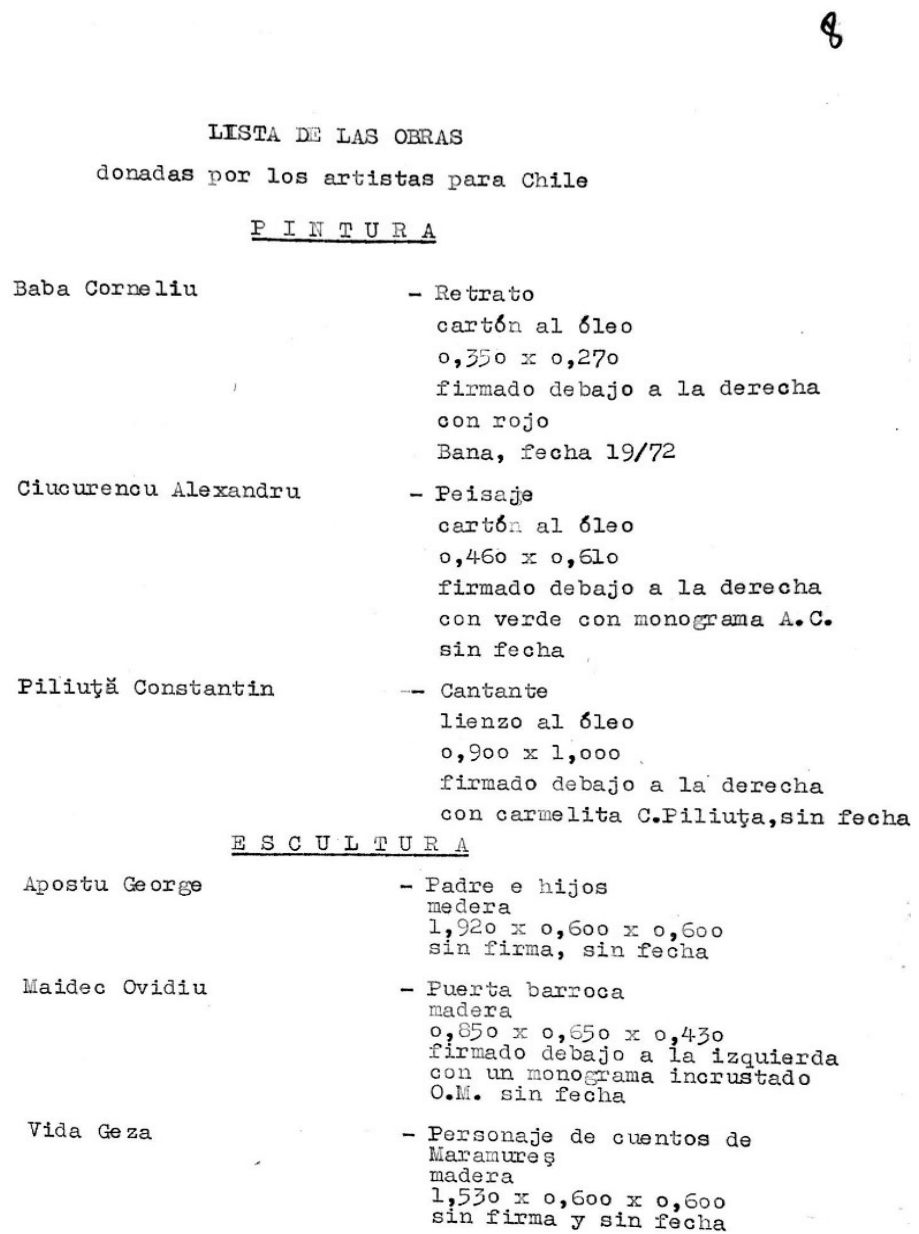

According to Kristine Khouri and Rasha Salti (2019), who analysed the large number of donations by Polish artists to the 1978 Palestinian Art exhibition, "it was common during the communist era for artworks to be collected from artists under the aegis of the People's Republic [of Poland]; the works were dispatched[...]perhaps via embassy and official contacts. Most artists[...]were unaware their work had been donated to an exhibition in solidarity with the Palestinian struggle" (Khouri, Salti, 2019).

${ }^{17}$ File 48/1972, UAP Fund, ANIC. 
Hence, in the Romanian case as well as in the Palestinian case we can suppose the Union of Artists received the Chilean call for artworks and designated the artists who would contribute. Thus, at a first glance, this would be another example of the bureaucratic, highly institutionalized Romanian artistic socialist field. Artists would not independently decide to support a certain cause, but would rather obey the hierarchical environment that was applied to the artistic world as well. The Romanian example thus negates the logic of artists acting in solidarity with a cause put forward by the socialist artists of Chile, and introduces the possibility of the institutionalization and politicization of the cultural field by the socialist state. This approach also applies to the transregional cultural links, which although were the result of the action of certain individuals in Chile and respectively Romania, are thereafter taken over by this institutional logic.

\section{Conclusions}

This article has put forward an argument for an investigation of the transregional links that were forged between countries of the Second Socialist World, through the specific case of the Museum of Solidarity. This museum constitutes a very good example of "cultural transnationalism" during the Cold War, and can act as a motif to further study the type of connections established during the 1970s and 1980s between various left-wing movements. Moreover, the article endeavours, through a micro-history approach, to investigate the case of the Romanian-Chilean connection, as mediated by the museum, as well as on the basis of archival material unused until now, which documents the cultural relations between the two countries.

The theoretical framework used is that of transnational and transregional links between communist regimes in the East and the South during the Cold War, specifically from the point of view of cultural relations, independent of the two super powers, the US and the USSR. Several arguments for this type of comparison were recalled stemming from very different theoretical perspectives: a history of art and the input of Piotr Piotrowski that proposed to create a "horizontal art history", the artistic projects that have investigated the transregional connections established by artists and museum projects in Latin America, Africa and the Middle East, and Cultural Cold War studies that have only marginally dwelt upon the connections between the East and the South.

Analysing the relations the Museum of Solidarity established with the Second Socialist World, with the countries in Eastern Europe, this article demonstrated that these were not central to the museum; only 64 of the 823 artists were from Eastern Europe and only 11\% of the 1,161 
artworks donated were from Eastern Europe. The aesthetic register also differed in relation to the artwork sent from other parts of the world. Eastern European artists privileged an abstract aesthetic vocabulary (the Polish case) or a neutral aesthetic imaginary (the Romanian example). Although these were socialist regimes, the type of connection they established rather depended on personal ties, as the Polish example shows. Otherwise, these relations remained highly institutionalized and bureaucratized as the Romanian case exemplified. In fact, as Hurtado-Torres recently showed, through the relationship between Josip Broz Tito and Allende, the relations between the Chilean regime and the communist regimes were not always an automatic response to ideological alignments, as it would appear at a first glance. ${ }^{18}$

Based on the unused archival documents of the IRRCS and of the Romanian Ministry of Foreign Affairs documenting the relation between Romania and Chile, this study showed what was the bureaucratic perspective offered by the institutional archives. The Romanian-Chilean cultural institutional relations were based on personal initiatives of Romanian exiles in Chile, and on the local initiatives, which invited the Romanian institution (IRRCS) to send them materials in order to organize local events. The types of events they organized testify to a traditionalist approach of the cultural field, emphasizing the expressions of popular art. The donation to the Museum of Solidarity of Chile, which was lost in the aftermath of the military coup of September 1973, attests of a bureaucratic logic; the Romanians sent artwork by important Romanian artists whose titles are not openly mobilizing or ideological, but on the contrary seem rather neutral. The six artists signed the list of artworks they donated. Moreover, although the Ceauşescu regime supported the arrival of 1600 Chilean refugees in 1974 in Romania, the regime did not participate in the efforts to support the Chilean cause in the following years, and did not collaborate with the museum in exile, the MIRSA because this was openly against the dictatorship of Pinochet with whom Ceausescu maintained relations. ${ }^{19}$ Ceausescu refused in his meetings with the leaders of the

\footnotetext{
${ }^{18}$ Hurtado-Torres $(2019,41)$ recalls how Tito favored, in the 1970 elections won by Allende, the candidate of the Christian Democratic Party, Radomiro Tomic. Another reason not to open up to Allende's victory was the Chilean Communist Party's support of the Soviet invasion of Czechoslovakia in 1968, along with Castro's support for Allende and Tito's "deeply negative opinion of Castro and his brand of socialism".

${ }^{19}$ According to the Museum's documents, for the period 1975-1990 there were only 2 Romanian artists who donated 3 artworks, and it seems these were in fact artists born in Romania, but who lived abroad, in France and Mexico. Museo Internationacional de la Resistencia Salvador Allende, MIRSA 1975-1990 (Santiago, Museo de la Solidaridad Salvador Allende, 2016), 124.
} 
Chilean Communist Party to follow the line imposed by the party in exile, in what concerns breaking relations with Chile under Pinochet.

The Romanian case shows that art considered in solidarity with the Chilean museum was traditional, nationalist, in agreement with Ceausescu's perspective on the arts, and in stark opposition to the logic of art of resistance and solidarity that was collected from other Western countries. Moreover, transregional and transnational studies discuss how individuals and networks of actors matter more than state relations, and the establishment and consolidation of cultural relations between Chile and Romania confirms it. But if the specific case of the relation between the Museum of Solidarity and Romania is analysed, we see that institutions matter more.

So, if the Museum of Solidarity represents a novel case study, by studying its relation with the Romanian regime of Nicolae Ceausescu what becomes evident is the difference in line with the reflections opened by Dragostinova and Fidelis. Interstate relations with socialist countries and personalized in the case of Poland, but not so in the case of Romania so the many layers of the transregional cultural relations have to be taken into account.

With respect to the study of Cultural Cold War relations, the example of the relationship between Romania and Chile as mediated by the Museum of Solidarity supports the idea of a highly bureaucratized institutionalized relation with the socialist regimes in Eastern Europe. Therefore, it was the cultural institutions that mattered, rather than personal initiatives on the Romanian behalf. An area for further research is how the Romanian officials acted in relation to their Chilean counterparts eventually by interviewing surviving artists from the Union of Artists that could testify of the reactions to the Chilean call of the Museum.

\section{Acknowledgements}

This work was supported by a grant of the Ministry of Research and Innovation, CNCS UEFISCDI, project number PN-III-P1-1.1-TE-2016-1369, financed by CNCS-UEFISCDI within

PNCDI III. "Crossing the Borders: Transnational Collaborations and Institutional Critique in Exhibitions of Eastern European Art during Late Socialism (1964-1989)”.

\section{References}

1. APOR, P. IORDACHI, C. (2013) Introduction Studying Communist Dictatorships: From Comparative to Transnational History. East Central Europe, 40, pp. 1-35. 
2. BAZIN, J, DUBOURG GLATIGNY, P., PIOTROWSKI, P. (2016) Introduction: Geography of Internationalism. In BAZIN, J, DUBOURG GLATIGNY, P., PIOTROWSKI, P. (eds.) Art Borders Artistic Exchange in Communist Europe [19451989]. Budapest, New York: CEU Press, pp. 1-28.

3. BERRÍOS, M. (2017) 'Struggle as Culture': The Museum of Solidarity, 1971-73. Afterall, 44, pp. 132-143.

4. BRAGHOORN, F. (1976) The Soviet Cultural Offensive. The Role of Culture Diplomacy in Soviet Foreign Policy. Connecticut, CT, Greenwood Press.

5. DRAGOSTINOVA, T, FIDELIS, M. (2018) Introduction. Slavic Review "Beyond the Iron Curtain: Eastern Europe and the Cold War", 77 (3), pp. 577-587. doi: 10.1017/slr.2018.200.

6. Exhibition "Past Disquiet. Narratives and Ghosts from the International Art Exhibition for Palestine, 1978", MACBA Barcelona.

7. Exhibition "Museo de arte de Lodz y el MSSA. Encuentros de solidaridad politica en el arte" curated by Maria José Delpiano at the Museo de la Solidaridad Salvador Allende in Santiago, Chile (15 October 2016 to 22 January 2017). http://mssa.cl/exposicion/poloniael-museo-sztuki-de-lodz-y-el-mssa-encuentros-de-solidaridad-politica-en-el-arte/

8. GOULD-DAVIES, N. (2003) The Logic of Soviet Cultural Diplomacy. Diplomatic History, 27 (2), pp. 193-214.

9. HOCK, B. (2018) Introduction - Globalizing East European Art Histories: The Legacy of Piotr Piotrowski and a Conference. In HOCK, B., ALLAS, A. (eds.) Globalizing East European Art Histories: Past and Present. New York: Routledge, pp. 1-22.

10. HURTADO-TORRES, S. (2019) The Chilean Moment in the Global Cold War International Reactions to Salvador Allende's Victory in the Presidential Election of 1970. Journal of Cold War Studies, 21 (3), pp. 26-55.doi:10.1162/jcws_a_00892, 41.

11. IACOB, B. (2013) Is it Transnational? A New Perspective in the Study of Communism. East Central Europe, 40, pp. 114-39.

12. JOSEPH, G. M. (2019) Border crossings and the remaking of Latin American Cold War studies. Cold War History, 21 (3), pp. 1-30. DOI: 10.1080/14682745.2019.1557824

13. KHOURI, K., SALTI, R. (eds.) (2019) Past Disquiet: Artists, International Solidarity and Museums in Exile. Warsaw: Museum of Modern Art in Warsaw. 
14. LEBEAU, E. (2019) When Solidarity became art: the Museo Internacional de la Resistencia Salvador Allende. In KHOURI, K., SALTI, R. (eds.) Past Disquiet Artists, International Solidarity and Museums in exile. Chicago: University of Chicago Press, pp. 325-341.

15. LEBEAU, E. (2018 a) El Museo Internacional de la Resistencia Salvador Allende (19751990). Transnacionalización del Museo de la Solidaridad en exilio. International Congress of Americanists, (Salamanca, Spain), pp. 1-9.

16. LEBEAU, E. (2018 b) Reflexiones epistemologicas sobre el objeto de 'collección'. Investigar los imaginarios del Museo Internacional de la Resistencia Salvador Allende (1975-1990). International Congress of Americanists, (Salamanca, Spain), pp. 1-10.

17. LEFFLER, M., WESTAD, O. (eds.) (2012) The Cambridge History of the Cold War, vol. I. Cambridge: Cambridge University Press.

18. MACHIAVELlO, C. (2016) Fibras Resistentes: Sobre El/Los/Algunos Museos de la Resistencia. In ZALDIVAR, C., YASKY, C. (eds.) Museo Internacional de la Resistencia Salvador Allende 1975-1990. Santiago, Museo de la Solidaridad Salvador Allende. Catalogue raisonné of MIRSA, pp. 28-65.

19. MIDDELL, M., (2019) Transregional studies. A new approach to global processes. in MIDDELL, M. (ed.) The Routledge Handbook of Transregional Studies. London, New York: Routledge, pp. 1-16.

20. MIKKONEN, S, KOIVUNEN, P. (2015) Introduction: Beyond the Divide. In MIKKONEN, S, KOIVUNEN, P. (eds.) Beyond the Divide Entangled Histories of Cold War Europe. New York: Berghan Books, pp. 1-17.

21. MIRANDA, (2013) Colección Solidaridad. In Museo de la Solidaridad Chile: Fraternindad, Arte y Política 1971-1973. Santiago.

22. PEDEMONTE, R. (2010) La diplomacia cultural sovética en Chile (1964-1973). Bicentenario, 9 (1), pp. 57-100.

23. PIOTROWSKI, P. (2018) Globalne ujęcie sztuki Europy Wschodniej. Poznán: Dom Wydawniczy Rebis.

24. ROJAS MIX, M. (2016) La solidaridad hecha museo. In ZALDIVAR, C., YASKY, C. (eds.) (2016) Museo Internationacional de la Resistencia Salvador Allende, MIRSA 19751990. Santiago, Museo de la Solidaridad Salvador Allende. Catalogue raisonné of MIRSA, 
pp. 14-27.

25. RUPPRECHT, T. (2015) Soviet Internationalism after Stalin. Interaction and Exchange between the USSR and Latin America during the Cold War. Cambridge: Cambridge University Press.

26. STONOR SAUNDERS, F. (1999) The Cultural Cold War. The CIA and the World of Arts and Letters. New York: the New Press.

27. VELÁZQUEZ, R. (2018) Modernism came flying: a micro-history of artistic internationalism and cultural encounters in US-Chilean relations, 1968. Cold War History, (19:2), pp. 209-232, DOI:10.1080/14682745.2018.1520212

28. WENDERSKI, M. (2015) The Influence of Interpersonal Relationships on the Functioning of the Constructivist Network. A Case Study of Poland and the Low Countries. Journal of Dutch Literature, 6 (2), pp. 1-20, 2.

29. YASKY, C. (2016) La perseverencia de la solidaridad en tiempos de Resistencia. In ZALDIVAR, C., YASKY, C. (eds.) Museo Internationacional de la Resistencia Salvador Allende, MIRSA 1975-1990. Santiago, Museo de la Solidaridad Salvador Allende. Catalogue raisonné of MIRSA, pp. 82-95.

30. YORDANOV, R. A. (2019) Warsaw Pact Countries' Involvement in Chile from Frei to Pinochet, 1964-1973. Journal of Cold War Studies, 21 (3), pp. 56-87.

31. ZALDIVAR, C. (ed.) (2013) 40 Años Museo de la Solidaridad por Chile. Fraternindad, Arte y Política 1971-1973. Santiago: Museo de la Solidaridad Salvador Allende.

32. ZALDIVAR, C., (2016) Museo en el exilio, un modelo de Resistencia. In ZALDIVAR, C., YASKY, C. (eds.) Museo Internationacional de la Resistencia Salvador Allende, MIRSA 1975-1990. Santiago, Museo de la Solidaridad Salvador Allende, pp. 8-12.

33. ZALDIVAR, C., YASKY, C. (eds.) (2016) Museo Internationacional de la Resistencia Salvador Allende, MIRSA 1975-1990. Santiago, Museo de la Solidaridad Salvador Allende. Catalogue raisonné of MIRSA.

34. ZOUREK, M. (2014), "Czechoslovak policy towards Chile in the 1970s and 1980s", Canadian Journal of Latin American and Caribbean Studies/Revue canadienne des études latinoaméricaines et caraïbes, 39:2, 211-228, 214. 